\title{
ANTHROPICAL STRUCTURES IN COASTAL SEDIMENTS
}

\author{
S.P. LEATHERMAN \\ National Park Service Cooperative Research Unit, University of Massachusetts,
} Amherst, Massachusetts 01003 , U.S.A.

\begin{abstract}
Intense hroman activity in the coastal zone has resulted in widespread deformation of coastal features. Vehicular and pedestrian traffic are the primary means of creating anthropical stmuctures. While the long-term preservation potential for these stmuctures is generally quite low, geologic investigations have shown that a large number of modern environments contain deformed layers in their sedimentary records.
\end{abstract}

\section{INTRODUCTION}

Coastal environments are becoming subject to greater recreational pressures in recent years. Part of this increased usage has taken the form of pedestrian and vehicular traffic. The detrimental effects of off-road vehicles (ORVs) on various landforms has only recently been evaluated (Wilshire et al 1977). Research at Cape Cod, Massachusetts has illustrated the magnitude and range of impacts on coastal ecosystems (Godfrey et al 1975, Leatherman 1977, Godfrey et al 1978). Evidence of these largescale impacts on the enviromment should be reflected in the recent record of the unconsolidated coastal sediments.

There have been few studies dealing with manmade deformation structures, although much emphasis has been placed on structural evidence in the interpretation of sedimentary environments. While textural and mineralogical information are quite important, recognition of structural relationships is often the key to identification. Process information can be directly extracted from the structural interpretations. Confusion in envirommental interpretations can result from several processes or agents producing similar structures. Van der Lingen and Andrews (1969) described circular depressions in recent beach sands which could have been the products of "air-heave" or deformation by horse-hooves. Experiments demonstrated that these structures were actually horse-hoof prints, modified and infilled by swash. Deery and Howard (1977) described pseudoconvolute bedding due to penetration of the washover fan surface by hooves and feet of vertebrate animals. These structures were deemed to be geologically significant because it was difficult to distinguish the pseudoconvolute bedding from true convolute bedding. Dionne (1972, 1973) has recognized structures on the tidal flats of the St. Lawrence Estuary of a peculiar origin. Some of the sedimentary features resembled animal trails, but these ribbed grooves and tracks were actually caused by ice break-up (Dionne 1972). Off-road vehicle tracks and pedestrian foot prints, which are discussed below, are the most common anthropical structures in coastal sediments.

\section{VEHICLE TRACKS}

The extensive usage of off-road vehicles in coastal areas has resulted in a very rutted surface appearance (Fig. 1). Hobbs (1977) has noted parallel zones of highly disturbed and contorted sediment layers contained within otherwise undisturbed beach and dune sands. These tire tracks from vehicles and airplanes have been found from
Alaska's Copper River Delta to the uninhabited barrier islands of Virginia's Eastern Shore. Hobbs (1977) termed these zones of deformation, which could be preserved in the stratigraphic record, as "autogenetic structures."

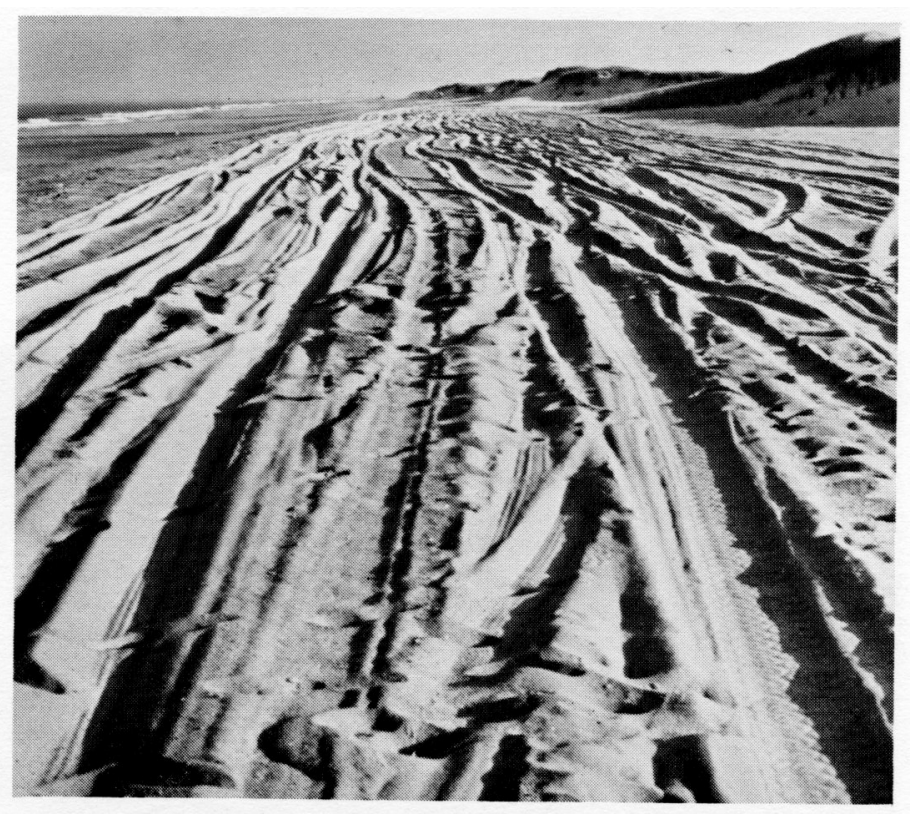

FIG. I Vehicular and pedestrian traffic have resulted in a highly roughened surface on the beach backshore of Nauset Spit, Cape Cod, Massachusetts.

Tire tracks on the backshore of Nauset Spit beach, Cape Cod, Massachussetts, were buried intact by waterlaid deposits. During spring tide conditions, wave swash overtops the beach berm, depositing sand on the backshore (Fig. 2). In this case, our offroad vehicle tracks were covered only minutes after the passage of the wheels through the area (Fig. 3). While the preservation potential for these convolute layers on beaches generally is quite low, these structures have also been found in more stable environments such as washovers.

While trenching a washover fan on Nauset spit, a convoluted layer was found at $0.75 \mathrm{~m}(2.5 \mathrm{ft}$. below the present surface (Fig. 4). From a core analysis, the layer would have appeared to exhibit steeply dipping beds, indicative of pyramidal dune bedding (Goldsmith 1973). The trench showed that this feature was actually a single vehicle track in horizontally-layered washover sediments. This vehicle gives some indication of the historical 

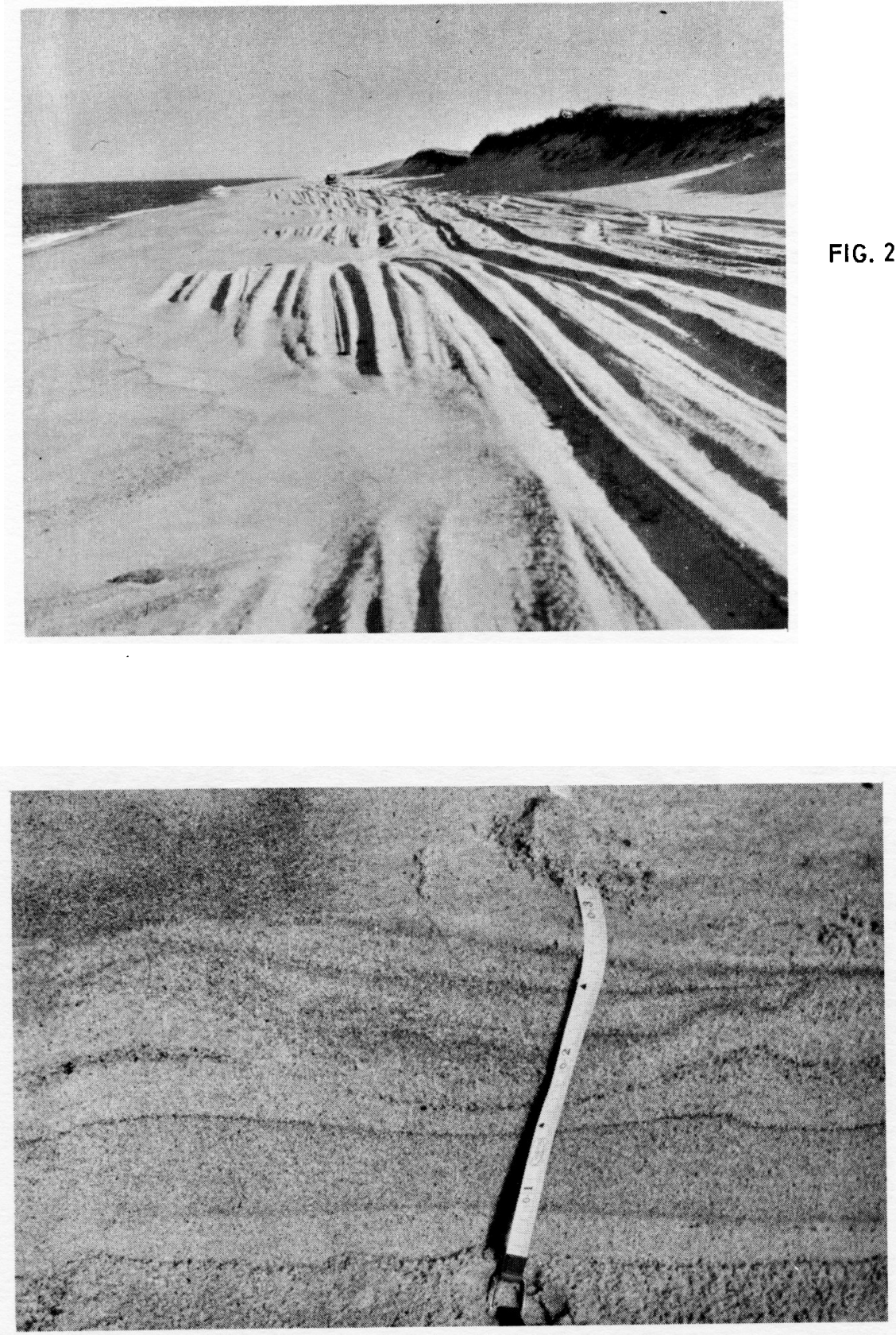

FIG. 2 Vehicle tracks are preserved on the beach backshore when covered by sediment transported by the swash overtopping the berm crest.
FIG. 3 A trench on the beach backshore showed that the tire tracks were preserved in tact by the depositional swash surges. usage of this area for vehicular passage. Since there are no other contorted layers in the section, except in the surface sediments, the entire sedimentary section may be the result of a single storm event. If there were many smaller overwashes spaced through time rather than one large overwash, then ORV tracks would be expected throughout the section for each of the old surfaces. If the regressive nature of this shoreline were reversed, then the tire tracks could be preserved indefinitely in the sedimentary record.

\section{PEDESTRIAN FOOT PRINTS}

Pedestrian traffic in coastal areas has also become of much concern due to damage inflicted on vegetation. In particular, dune grass is very sensitive to the stress of foot traffic, and dune blowouts soon develop. Although foot traffic does not generate the deep ruts of vehicle tires, the prints are much in evidence in soft, unconsolidated sediments. McKee and Bigarella (1972) have described contorted laminae from loading, caused by walking on coastal dune surfaces in Brazil. Leatherman and Williams (1977) trenched a washover fan at Assateague Island, Maryland, and found evidence of human disturbance. Surveyors, walking on the fan surface, had caused contorted layers and "micro-faulting." The alternating layers of quartz and concentrated heavy minerals apparently acted in an elastic nature 


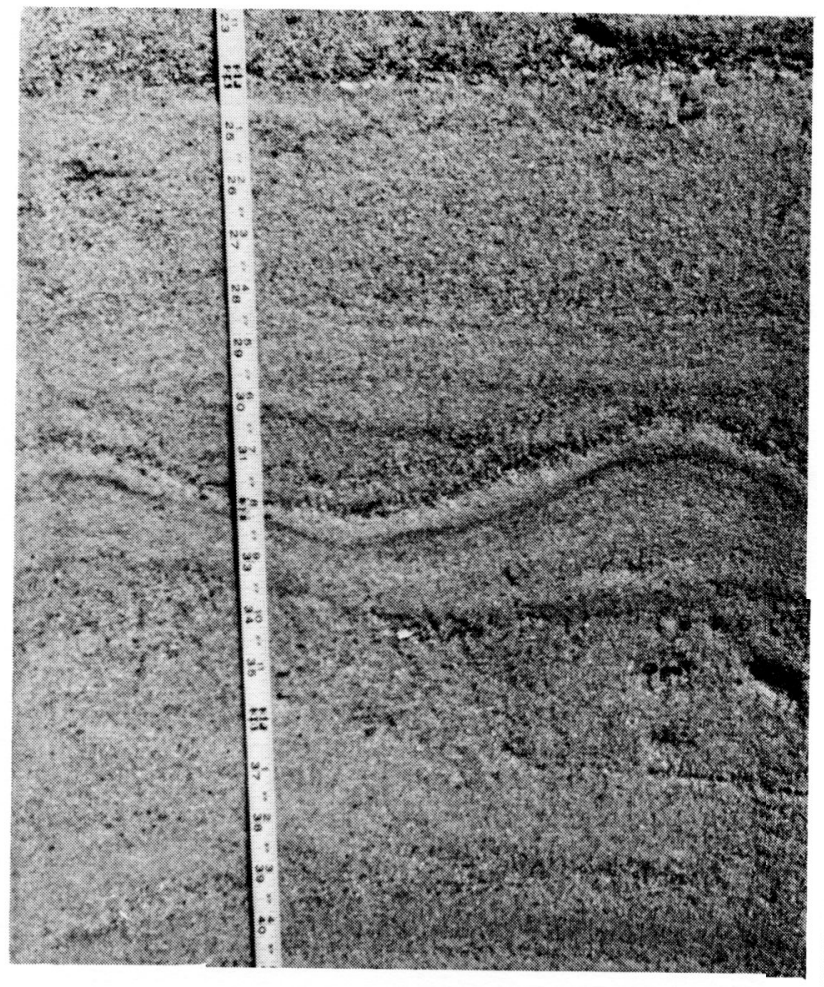

FIG. 4 A convoluted layer was found at two and one-half feet below the surface of a washover on Nauset Spit. This structure was interpreted to be a vehicle track since it is similar in size and form as known tire tracks (see Figure 3).

FIG. 5 A contorted bed was exposed for several hundred meters along a wave-scarped barrier dune at Fire Island National Seashore, New York.

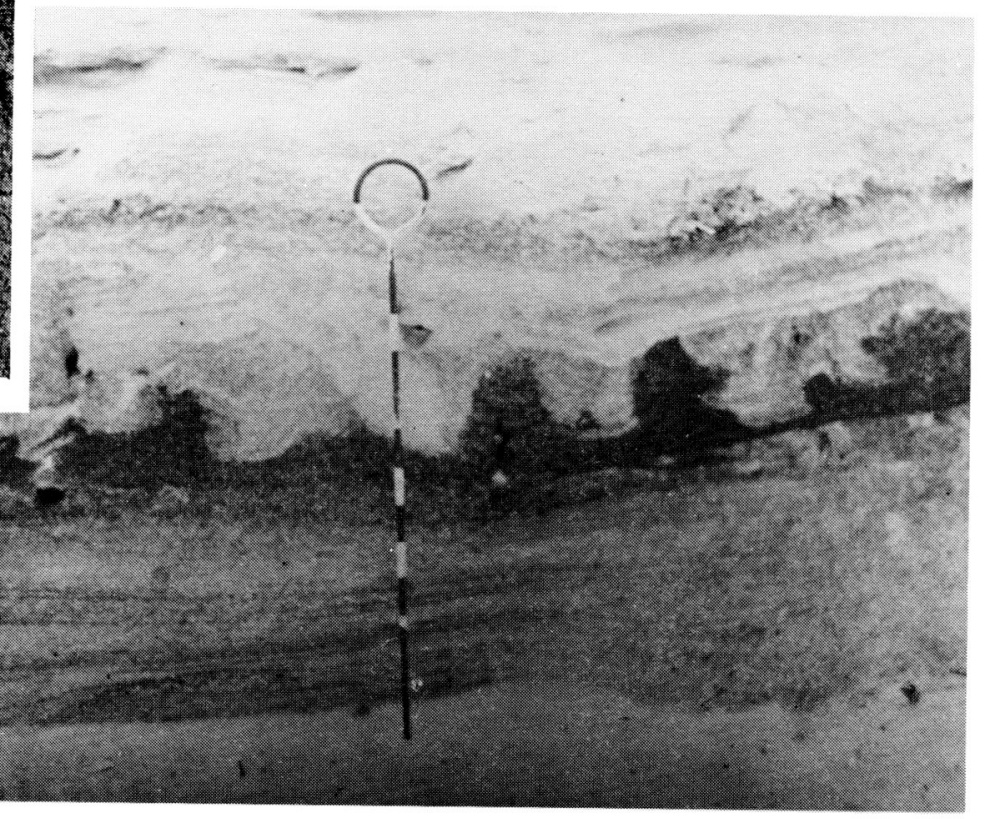

FIG. 6. The contorted beds at Fire Island are believed to be foot prints on a post-storm washover or beach backshore surface that was subsequently covered by eolian sedimentation.

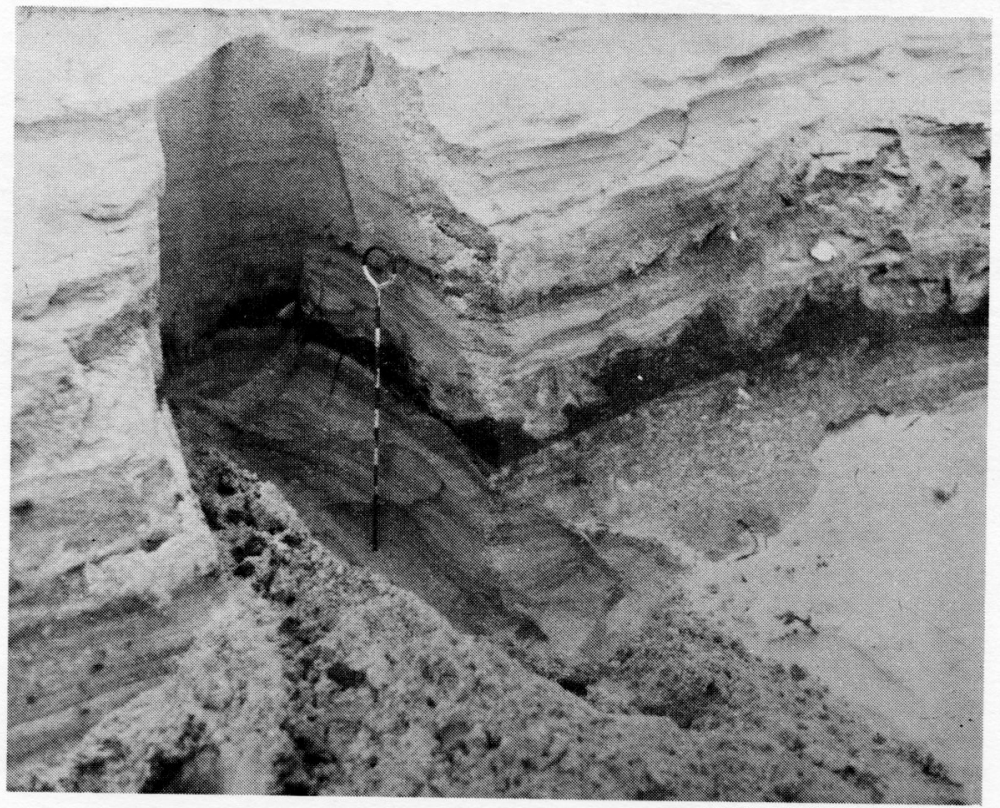


so that slippage of several centimeters occurred along certain "fault" planes. These anthropical structures were buried to a depth of $40 \mathrm{cms}$ by an overwash generated by a large northeaster (Leatherman et al 1977).

At Fire Island, New York, a curious contorted bed was found at the base of a $3-\mathrm{m}$ high barrier dune (Fig. 5). The layer was shown to have a horizontal extent of hundreds of metres, as exposed in the wave-scarped dune face. Further examination showed that these features, which are believed to be footprints, were irregular in form in all three dimensions (Fig. 6). McCormick (1975) recognized some scour-and-fill structures, produced by retreat of a scarp up the beach, which are similar to the convoluted structures, but are not as irregular and jagged in appearance as the foot prints.

It is somewhat difficult to reconstruct the historical development of this area, but the concentrated heavy mineral layer would indicate a hydraulic origin (McCormick 1975). Therefore, this area was either a large washover area or beach backshore environment with intense pedestrian traffic in evidence. It is a part of Robert Moses state Park, which has historically been a favorite site for seashore recreation. Since the very highly contorted nature of the beds has been preserved, it is believed that the sand that buried this old surface was wind-blown. Rapid dune growth was probably facilitated by the use of snow-fencing. These anthropical structures would probably have been incorrectly interpreted without previous recognition of these features and such $\dot{a}$ large exposure.

\section{CONCLUSIONS}

Anthropical structures are rather common in recent coastal sediments, particularly along barrier island beaches. The geologist who uses structure as the primary criterion for interpretation of process should be aware of the potential for maninduced convolute bedding structures. The examples cited in this discussion illustrate the wide range in geographic setting and type of sedimentary environment where anthropical structures can be found.

\section{REFERENCES}

DEERY, J.R. and HOWARD, J.D. 1977. Origin and character of washover fans on the Georgia coast, U.S.A.; Transactions Gulf coast Association of Geological Societies, v. 27 , pp. 259-271.

DIONNE, J.C. 1972. Ribbed grooves and tracks in mud tidal flats of cold regions; Journal of Sedimentary Petrology, v. 42, pp. 848-851.
DIONNE, J.C. 1973. Monroes: a type of so-called mud volcanoes in tidal flats; Journal of Sedimentary Petrology, vol. 43, pp. 848-856.

GODFREY, P.J., BRODHEAD, J., WALKER, H., GILLIGAN, J. and DAVIS, A. 1975. Ecological effects of offroad vehicles in Cape Cod National Seashore, Massachusetts, Preliminary Report; Univ. of Mass. NPSCRU Report 18, $121 \mathrm{pp}$.

GODFREY, P.J., LEATHERMAN, S.P. and BUCKLEY, P.S. 1978. The effects of off-road vehicles on coastal ecosystems; Proceedings of the Coastal zone 78 Conference, ASCE, pp. 581-600.

GOLDSMITH, V. 1973. Internal geometry and origin of vegetated coastal sand dunes; Journal of Sedimentary Petrology, vol. 43, pp. 1128-1142.

HOBBS, C.H. 1977. Some deformation structures in recent beach sands, in Goldsmith (ed.), Coastal Processes and Resulting Forms of Sediment Accumulation, Curritick Spit, Virginia-North Carolina; VIMS Publication No. 143, p. 33-1.

LEATHERMAN, S.P. 1977. The effects of off-road vehicles on the geomorphology of dunes in Cape Cod National Seashore; Proceedings of the First Conference on Scientific Research in the National Parks, 15 pp.

LEATHERMAN, S.P. and WILLIAMS, A.T. 1977. Lateral textural grading in overwash sediments; Earth Surface Processes, vol. 2, pp. 333-341.

LEATHERMAN, S.P., WILLIAMS, A.T., and FISHER, J.S. 1977. Overwash sedimentation associated with a large-scale northeaster; Marine Geology, vol. 24, pp. 109-121.

MCCORMICK, L. 1975. Shinnecock flood tidal delta and coastal stabilization problems west of Shinnecock Inlet; in M.P. Wolff (ed.), Guidebook to Field Excursion, 47 th Meeting of New York State Ecological Assoc., pp. 51-72.

MCKEE, E.D. and BIGARELLA, J.J. 1972. Deformation structures in Brazilian coastal dunes; Journal of Sedimentary Petrology, vol. 42, pp. 670-681.

VAN DER LINGEN, G.J. and ANDREWS, P.G. 1969. Hoofprint structures in beach sand; Journal of Sedimentary Petrology, vol. 39, pp. 350-357.

WILSHIRE, H.G., BODMAN, G.C., BROBERG, D., KOCKELMAN, W.J., MAJOR, J., MALDE, H.E., SNYDER, C.T. and STEBBINS, R.C. 1977. Impacts and management of offroad vehicles; Report of the Committee on Environment and Public Policy, Geological Society of America, 8 pp. 